\title{
Animal-rights militancy exported to US and Europe
}

Some US and European animal-rights activists are adopting the illegal tactics of extreme UK groups, say police and groups monitoring protest activity. They note that just as incidents seem to be declining in Britain, they are rising elsewhere.

"When it comes to animal-rights extremism, there is a body of knowledge in the United Kingdom," says a spokesman for the UK police's National Extremism Tactical Coordination Unit, set up in 2004 to tackle illegal animal-rights activity. He says the UK scene has links with the United States and activity on mainland Europe directly related to that in Britain."

Mark Matfield is director of the European Biomedical Research Association, a London-based group that lobbies the European Union for better support and protection for researchers who use animals. He says that more sophisticated policing and tougher legislation have seen UK activity shift overseas.

"In the first half of 2005, there was an increase in illegal actions in Sweden, Switzerland, the Netherlands and Germany," Matfield says. "Much of it is either organized by British activists, or

European police forces have detained British activists after illegal incidents, he says. Research laboratories are targeted indirectly, by attacks and threats to the property of their staff and those of that "there has been an increase in extremist they have travelled abroad to get involved."
US ILLEGAL
ANIMAL-RIGHTS PROTESTS

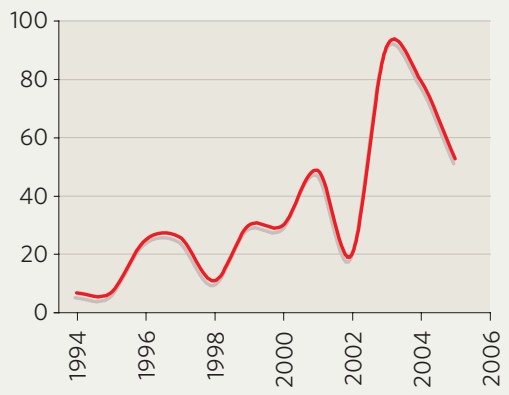

companies that work with them. And UK activist groups such as the Animal Liberation Front and Stop Huntingdon Animal Cruelty (SHAC) now have active branches in other European countries and the United States.

Carrie Wolinetz, spokeswoman for the Federation of American Societies for Experimental Biology, a Washington DC-based group that promotes biological research, draws the link explicitly. "The SHAC campaign and Animal Liberation Front started in the United Kingdom and were exported - unfortunately, because they were effective."

The fierceness of US animal-rights activism currently lags about five years behind the British, says George Goodno, spokesman for the Foundation for Biomedical Research, a Washington DC-based nonprofit organization that defends animal research and collects information on illegal protests (see graph).

"It definitely is ramping up," he says.

The United States became aware of the growing extremist activity in the country this September when Huntingdon Life Sciences, a research organization that conducts animal testing, was denied a listing on the New York Stock Exchange at the last minute. It was widely reported that this was owing to threats from SHAC, which proclaimed victory.

Parallel bills being considered in the US House and Senate would make it easier to prosecute animal-rights activists who cause economic damage to companies, academic laboratories and zoos; Britain passed similar legislation earlier this year. The US bills could mean a ten-year jail sentence for any activist who costs a company more than $\$ 100,000$.

John Lewis, a deputy assistant director at the Federal Bureau of Investigation with responsibility for counterterrorism, testified at a hearing on the Senate version of the bill. He said that activists kept mostly to a nuisance level of illegality threatening phone calls, vandalism and raucous demonstrations in front of executives' houses.

Goodno has collected reports of 80 illegal actions by animal-rights activists in the United States in 2004, but notes that as the main tactic is constant low-grade harassment, these incidents are "the tip of the iceberg".

Emma Marris and Tom Simonite

\section{TV show gives research lobbyist a rat's-eye view of laboratory life}

To counter animal-rights activists, UK lobby groups that support animal research have launched their own media campaign.

In one reality television show, called The Devil's Challenge, the in animal labs.

Simon Festing, director of the Research Defence Society in London, agreed to do the show, which was designed to test his belief in animal experiments. "We need to face the fact this is how the media works," he says, "and it's a good way to get our arguments out there." director of one such group is caged and subjected to procedures used
Kept in a cage proportional in size to those used to house lab mice, Festing was subjected to a number of experiments. One recreated a test for pain, where rats are placed on a hotplate and the time until their feet twitch is recorded. Another, investigating wind chill, involved a dousing in water and a wind machine.

Other challenges brought him face to face with animal-rights activists and sent him to a primary school, where he tried unsuccessfully to persuade children to donate their cats for animal research.

Festing admits the experiences

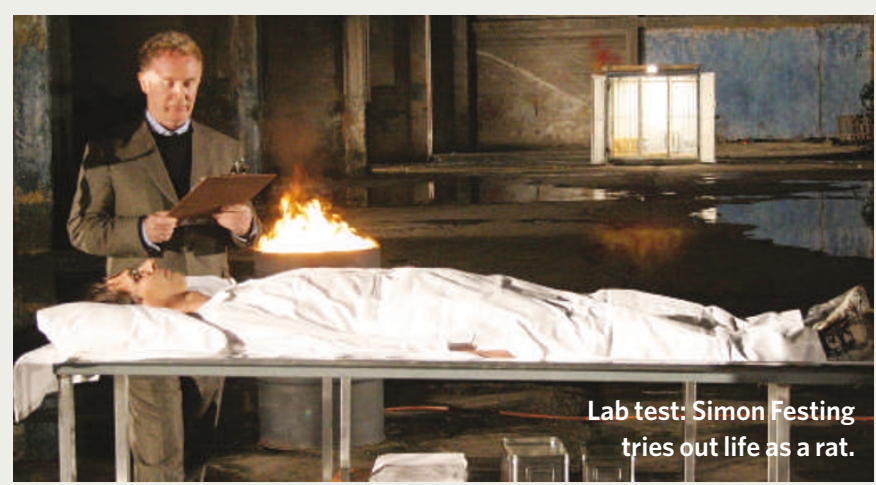

were difficult. "It did make me think harder about the welfare of lab animals," he says. But nevertheless, he remains a firm believer in the need for animal research. The Devil's Challenge is broadcast on the UK digital channel More4 on 14 December. 